\title{
Ormhäxan, Dragons, Partuition and Tradition
}

Stephen Mitchell

Harvard University

Medieval Nordic vernaculars routinely use the terms dreki (pl. drekar), 'dragon', and ormr (pl. ormar), both 'serpent' and 'dragon', in often overlapping ways, although clearly dreki, a word of foreign origin (< Latin draco, from Greek drakōn) has the more restricted range, never referring to snakes as such, but always, and only, to the kind of serpentine beasts known from myth and legend. ${ }^{\mathrm{I}}$ By contrast, ormr, cognate with Old English wyrm 'snake,' 'dragon' and so on, is employed to mean both the actual reptiles of the suborder Ophidia and cryptozoological monsters. So intertwined are the two in medieval texts and in artistic representations that one scholar has suggested the Swedish neologism drakorm (pl. drakormar) as a means of referring to the two as a group. ${ }^{2}$

In surviving texts concerned with Old Norse mythological and legendary traditions, modern readers encounter three especially well-known dragons: Niðhoggr, the Miðgarðsormr, and Fáfnir. There are other named dragons and other terms, of course, as Snorri remarks in his Skáldskaparmál:

Pessi eru orma heiti: dreki, Fáfnir, Jormungandr, naðr, Niððoggr, linnr, naðra, Góinn, Móinn, Grafvitnir, Grábákr, Ófnir, Sváfnir, grimr. $^{3}$

These are the names for serpents: dragon, Fafnir, Iormungand, adder [naðr], Nidhogg, viper [naðra], ${ }^{4}$ Goin, Moin, Grafvitnir, Grabak, Ofnir, Svafnir, masked one. ${ }^{5}$

How to cite this book chapter:

Mitchell, S. 2019. Ormbäxan, Dragons, Partuition and Tradition. In: Wikström af Edholm, K., Jackson Rova, P., Nordberg, A., Sundqvist, O. \& Zachrisson, T. (eds.) Myth, Materiality, and Lived Religion: In Merovingian and Viking Scandinavia. Pp. II 5-I39. Stockholm: Stockholm University Press. DOI: https://doi.org/ro.I6993/bay.f. License: CC-BY. 
What these legendary drakormar of Norse tradition have in common with the well-known dragons of Christian tradition, such as those that do combat with Christian heroes such as Saint George, is that they are typically seen to have negative associations, that is, generally negative and adversarial relations with human society: according to Veluspá in GKS $23654^{\text {to }}$, Níðhọggr, for example, inn dimmi / dreki fliúgandi ('the dark dragon flying') bears corpses $i$ fioðrom (lit., in [his] feathers'; Voluspá (K) st. 63 cf. Voluspá (H) st. 58) and is said in Grimnismál (st. 35) and Gylfaginning to gnaw (skerðir) at the roots of the World Tree.

This adversarial "man versus monster" scenario, the central image of the various story lines gathered as motifs A876, Aro82.3 and so on in The Motif-Index of Folk-Literature, ${ }^{6}$ is one that has ancient roots: not only the North Germanic peoples but also many other Indo-European cultures - i.e., Italic, Indo-Iranian, Celtic, Greek, Anatolian and other historically- and linguistically-related traditions - were, according to Calvert Watkins' How to Kill a Dragon: Aspects of Indo-European Poetics, ${ }^{7}$ inheritors of a millennia-old formula of the following sort:

(HERO) SLAY ( * $\left.g^{u} h e n-\right)$ SERPENT (WITH WEAPON; alt., WITH COMPANION)

It is, of course, a tale that recurs in the myths and legends of many Indo-European cultures, for example, in the storied confrontations between Zeus and Typhon, Herakles and the Hydra, Perseus and the Gorgon, Indra and Vrtra, and, in the Nordic case, Pórr and the Miðgarðsormr.

Given this well-documented archaic story pattern and such popular Christian presentations of dragons in the Nordic Middle Ages as the legend of Saint George, it seems that the principal way these beasts ought to be understood is within an adversarial context; however, several scholars have been at pains to argue for a different perspective on pre-Christian perceptions, and uses, of dragons. Basing his interpretation on close examination of Bronze Age rock art and images on bronze objects, Flemming Kaul has proposed an integrated understanding of what he has termed the religion of "the solar age" (solalderen). ${ }^{8}$ According to Kaul's analysis, this is a belief system connected to a social elite exercising 
control of, and trade in, bronze. ${ }^{9}$ In it, the drakorm provides assistance to the sun in its daily movement by leading it below the horizon for its nocturnal aqueous passage. ${ }^{\circ}$

On the significance of such an understanding of Bronze Age religion in the North for the Germanic Iron Age many centuries later, Kaul thinks such continuity unlikely, mainly due to what he understands to be two periods of disruption: one c. $500 \mathrm{BC}$ with a change in ritual patterns, and another, c. $500 \mathrm{AD}$, with the establishment of a religion centered on the Æsir. But, even if he thinks the possibility slight of there being any meaningful comprehensive connections between the Bronze Age materials and, for example, later written sources, Kaul concedes that some of the earlier motifs, including the snake motif, may have been transformed in ways that allowed them to survive into the Iron Age. ${ }^{\text {I }}$

Birgitta Johansen, also an archaeologist, concludes as well that there may have been generally positive relationships of drakormar to human society. Treating the Roman Iron Age up through the Middle Ages (200 CE -I400 CE), Johansen examines the evolution of social and mental constructs, especially as these are to be inferred from the natural and built landscapes (e.g. hill forts, stone walls), and their interrelationships. Johansen's interpretation relies heavily on what she sees as the contrasting views of pagan vs Christian Scandinavia, especially as these perspectives are employed in dragon imagery on rune stones. ${ }^{\mathrm{I} 2}$ Johansen argues that the previously positive connection between drakormar and women turns negative under Christianity's influence:

My conclusion is that women are the users of the dragon (even explicitly against men) and that the dragon protects women. The dragon fights with men and it kills men. These roles eventually changed, the dragon increasingly becoming a threat to men and something men could control only by killing. In addition it became, during the Middle Ages and under Christian influence, a deadly threat to women too. ${ }^{\mathrm{I}}$

Thus, against the view that human relations to drakormar were necessarily negative, as in so many Indo-European sources and such Old Norse narratives as those about Pórr and the Miðgarðsormr, an alternative, positive interpretation also emerges 
for the pre-Christian era. Recognizing the possibility then that there may have existed two distinctly different interpretations of drakormar in the Iron Age, how might our understanding of the drakorm figure as seen in Gotland be re-interpreted?

Drakorm elements figure strongly in the island's art tradition, and a number of Gotlandic picture stones provide important clues about the drakorm's status. Frequently, these images come from the earliest era of the Gotlandic picture stones, ${ }^{14}$ a turning point in the history of religious and cultural life in northern Europe.

From the earliest periods, Lindqvist's group Aa, now understood to include the $2^{\text {nd }}$ through the $6^{\text {th }}$ centuries, ${ }^{\mathrm{I} 5}$ such $d$ rakorm images as Martebo Church (G 264) (Fig. I) and Hangvars Austers I, for example, testify to the popularity of the dragon-snake motif within the island's art traditions. For the most part, these depictions appear to fall well within the adversarial dragon tradition. ${ }^{16}$ A related, but much more complex and divergent, use of drakormar is also one of the best-known Gotlandic picture stones to the world at large, namely, the remarkable monument from Smiss in När Parish, discovered in I95 5, sometimes called the "snake witch stone" (Swedish ormbäxan, alt., ormtjuserskan). ${ }^{17}$ När Smiss III (Fig. 2) is usually dated to the $6^{\text {th }}$ to $7^{\text {th }}$ centuries (although some have suggested that it might be from as early as the $5^{\text {th }}$ century). ${ }^{18}$ In it, rather than the dominating central whirling solar figures on Martebo Church (G 264) and Hangvars Austers I, När Smiss III

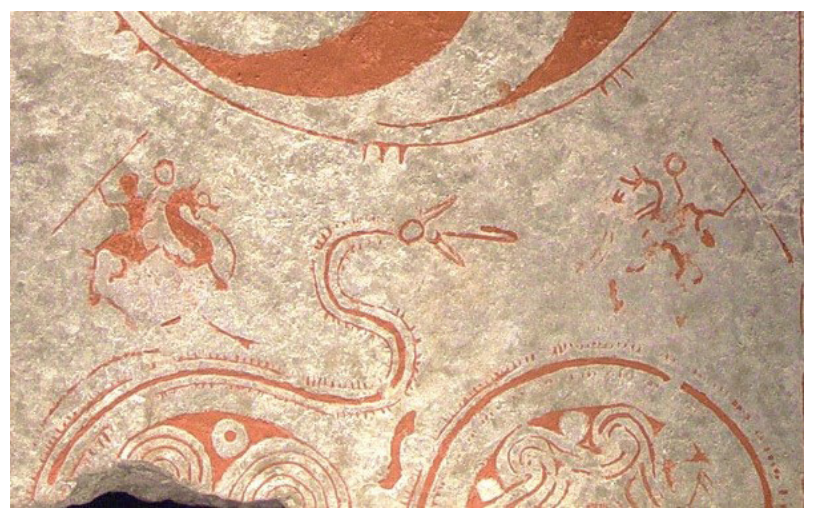

Figure 1. Martebo Church (G 264). Photographer: Stephen Mitchell. Copyright: Stephen Mitchell, License: CC-BY-NC-ND. 


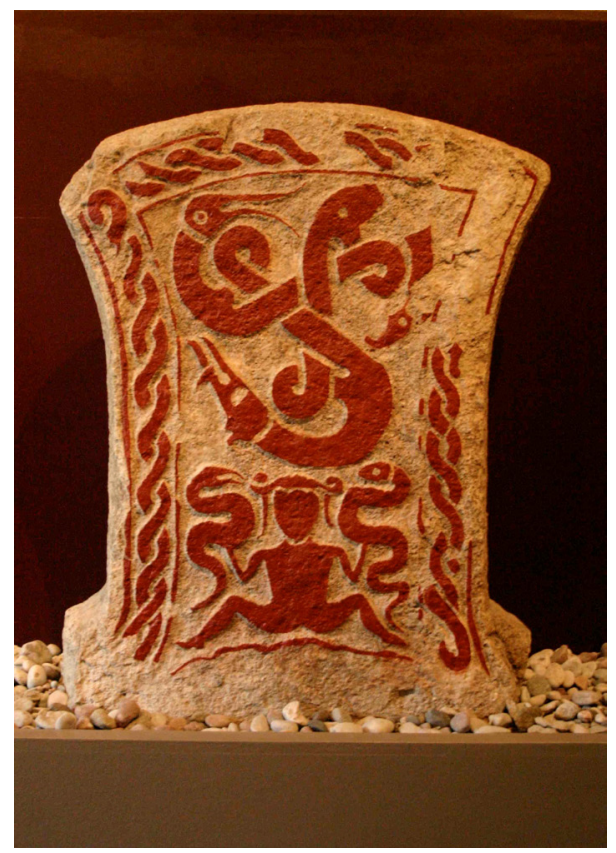

Figure 2. När Smiss III. Photographer: Stephen Mitchell. Copyright: Stephen Mitchell, License: CC-BY-NC-ND.

has instead a large triskele of three animals, often interpreted as a boar, a raptor, and a drakorm. Beneath this group is the figure of a human, generally, although not always, believed to be a woman, legs outstretched, holding two differing drakormar, one in either hand.

Interpretations of this stone's origins, history and meaning have been much discussed, although little agreed on - already its discoverer, Sune Lindqvist, brought not only Norse but also Celtic and Minoan traditions into the debate and these possibilities have tended to dominate discussion ever since. The stone has, for example, been understood to be a product of Celtic artisanship representing Daniel in the lion's den; ${ }^{19}$ others have also promoted possible Celtic connections, especially to the degree to which the image has been likened to the god, Cernunnos, as presented on the Gundestrup Cauldron. ${ }^{20}$ Karl Hauk sees in the figure a shapeshifted Óðinn in the form of a Seelenführer. ${ }^{21}$ And comparisons 
with the famous Minoan snake goddess figurines from the "houses of the double-axe" in Knossos and other Cretan towns are highly suggestive but of uncertain value given our current state of knowledge. The very uniqueness of this stone among Gotlandic picture stones makes the object difficult to assess, although one need not be quite so pessimistic as the Harrisons, who include the stone in their IOI föremål ur Sveriges historia noting simply that "we haven't a clue about what the stone says". ${ }^{22}$

By contrast, local historians and other enthusiasts have been neither silent nor uncertain about this remarkable stone, and we may, in fact, be able to provide a context which at the very least situates När Smiss III within an empirically-based matrix, such that it no longer seems so utterly sui generis. Of particular interest, despite being half a millennium later than När Smiss III, has been a $\mathrm{I}{ }^{\text {th }}$-century stone relief at Väte Church, Gotland:

It has sometimes been suggested that such scenes are legacies of a pre-Christian belief in Terra mater, the earthmother, nursing beasts, including serpents. Another, and in my opinion likelier,

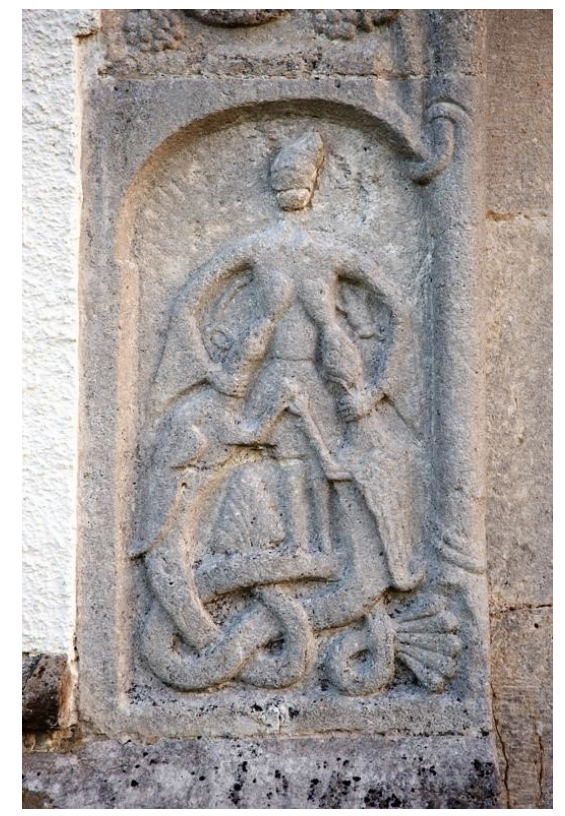

Figure 3. Väte Church, Gotland. Photographer: Bengt A. Lundberg. Copyright: Riksantikvarieämbetet, License: CC-BY-NC-ND. ${ }^{23}$ 
interpretation is that it reflects an interest in such vision literature as e.g. the $4^{\text {th }}$-century Vision of Saint Paul, the $5^{\text {th }}$-century Apocalypse of Elijah, or the (contemporary) $\mathrm{I}{ }^{\text {th }}$-century Vision of Alberic, all of which present women condemned to nurse serpents in Purgatory/Hell, because they have refused to care for orphans, or, in other instances, their own children. And in Continental church art, these unusual scenes of multi-specied nursing are understood to be a punishment for lust and debauchery, an idea occasionally applied to Väte as well $;^{24}$ moreover, similar scenes are also found in medieval homiletic literature, which again point to envy and lust as the causes of this unusual suckling. ${ }^{25}$ Recent arguments have pushed back against this ecclesiastical interpretation and contended anew that it is, in fact, Terra mater and not Luxuria that is being presented here and elsewhere in Nordic contexts. ${ }^{26}$

Importantly, one of the other sites comes from the church at Linde on Gotland, part of a baptismal font described as showing "a standing woman with a 'snake' $[\mathrm{orm}]$ at one breast". ${ }^{27}$ Naturally, the origin of the medieval drakorm-nursing images at Väte and Linde are most easily explained by these ecclesiastical references - yet whatever the Church's specifically theological rationale, nothing about this scene dictates that islanders who knew of a traditional association of women and drakormar could not interpret it in ways that were convivial to local beliefs and customs, an association that could, in fact, have played a role in the Church's selection of this theme. The two images at Väte and Linde are hardly a large dataset and one might reasonably conclude that these unusual human-drakormar interactions are merely examples of the so-called "infinite monkey theorem". Yet, as already strongly hinted at in Peel's edition and translation of medieval Gotlandic law and legend, ${ }^{28}$ there are, in fact, several other significant indications of a local tradition involving drakormar.

Although the human figure on the lower portion of När Smiss III is unique on Gotland, the triskele design on the upper portion is not. In fact, in reviewing the archaeological record from the period 550-750 CE, ${ }^{29}$ it is clear that designs similar to the När Smiss III triskele are a common feature of Gotlandic iconography throughout these pre-Viking periods, as in the following examples of perforated discs: ${ }^{30}$ 
The design of these artifacts, of which there are a great many from Gotland, strongly resembles the triskele on När Smiss III (although it shows three different animals), especially when it is presented in a similar style (Fig. 5):

One particularly interesting item in this inventory (item $\mathrm{c}$ in Fig. 4), as noted already in Peel, ${ }^{3 \mathrm{I}}$ comes from an early $9^{\text {th }}$-century Gotlandic grave for a woman at Ihre in Hellvi Parish in northeastern Gotland. Although the grave itself dates to the $9^{\text {th }}$ century, ${ }^{32}$ it has been argued that the object may date to the period 650-700 CE. ${ }^{33}$ One possible interpretation of this chronology would be that the disc, as a noted archaeologist suggests "might have been an antique when it was buried and this raises the possibility of such decorative discs having been heirlooms passed from mother to daughter" ${ }^{34}$

The continuity of these ornamental discs, their style, and their concern with drakormar brings to mind, as is occasionally mentioned on online sites about Gotland, that also concerned with women and serpents is an important episode in the so-called Legendary History of Gotland from the $3^{\text {th }}$ century:

Pissi Pieluar hafpi ann sun, sum hit Hafpi. En Hafpa kuna hit Huitastierna. Paun tu bygpu fyrsti a Gutlandi. Fyrstu nat, sum paun saman suafu, pa droymdi henni draumbr, so sum prir ormar varin slungnir saman $i$ barmi hennar, ok pytti henni sum pair skripin yr barmi hennar. Pinna draum segpi han firir "Hafpa, bonda sinum. Hann "rep draum pinna so:

'Alt ir baugum bundit.

Boland al pitta varpa, ok faum pria syni aiga.' 35

This same Pieluar had a son named Hafpi, and Hafpi's wife was called Huitastierna. These two were the first to settle in Gotland. The first night that they slept together, she dreamed a dream. It was just as if three snakes were coiled together within her womb, and it seemed to her as though they crawled out of her [womb $]^{36}$. She related this dream to Hafpi, her husband, and he interpreted it as follows:

'Everything in rings is bound.

Inhabited this land shall be;

we shall beget sons three.' 

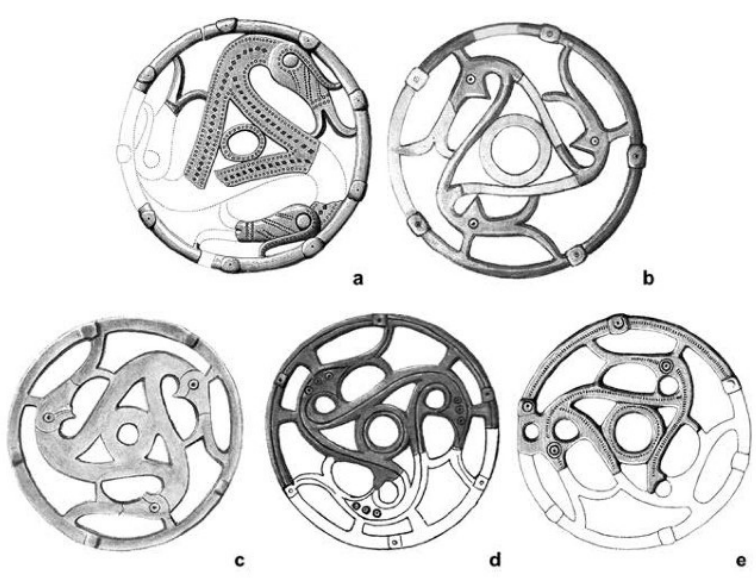

$50 \mathrm{~mm}$

Figure 4. Perforated disks. From Pearl 20I4, original drawing from Nerman et al. I969-I975. Copyright: Pearl, Frederic; The Swedish Archaeological Society; Kungl. Vitterhets Historie och Antikvitets Akademien. License: CC-BY-NC-ND.

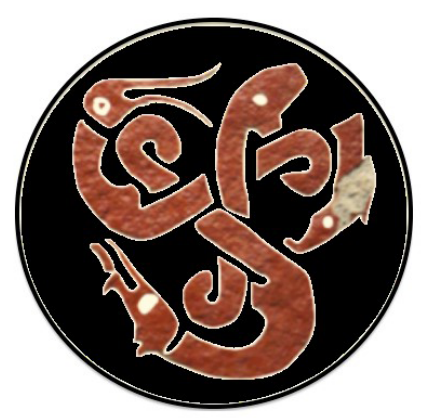

Figure 5. När Smiss III triskele presented in the style of an ornamental disc. Copyright: Stephen Mitchell, License: CC-BY-NC-ND.

This legendary text as a whole has been the subject of much discussion over the decades, ${ }^{37}$ and although its immediate context the Laws of Gotland - suggests that it largely functioned as a framing device for these important documents, few doubt that much of the material in the history offers us insights into the early 
history and traditions of the island..$^{8}$ The opening settlement or foundation legend, for example, has numerous parallels, including the three brothers, but virtually without parallel is the notion of Huitastierna dreaming of having three snakes coiled in her womb who are subsequently born and who, as humans, settle the island.

A somewhat similar tale is the dream reported about Clytemnestra in the second of Aeschylus' Oresteia trilogy, Choephoroi (The Libation Bearers), according to which Clytemnestra has given birth to a monstrous and vengeful snake. But even if the basic idea - an elite woman giving birth to one or more snakes - is the same, it is in one instance meant to be a real snake and in the other a dream to be interpreted, like the cows and corn that Jacob reveals to pharaoh (Genesis 40-4I); moreover, the consequences of the dreams are quite different. ${ }^{39} \mathrm{On}$ the other hand, the association of snakes with birthing can boast many parallels: the resemblance of entwined snakes to the umbilical cord, a perception that leads to the connection, and perhaps even metonymy, of this funiculus and snakes, is a phenomenon well-documented in a variety of ancient and modern cultures..$^{\circ}$ Moreover, the skin-shedding or sloughing (edysis) of snakes has led to the association of these animals with concepts of re-birth in e.g. ancient Egyptian and Mesoamerican cultures.

The occasional attempts to link this episode of the Legendary History to När Smiss III might easily be dismissed as an exuberant exercise in local pride, yet viewed in the context of the decorative disc from Ihre and the other Gotlandic drakorm triskeles that suggest a long-standing preoccupation with these motifs, it is worth noting that that keen native observer of Gotlandic history and culture, Hans Nielsön Strelow (I 580 -1656), makes much of the continued popular importance in his day of Huitastierna and her role in creating the identity of the island, concluding by saying that "The Gotlanders ascribe much to her" (Hende tilskrifuer Guthilenderne megit). ${ }^{4 \mathrm{I}}$

Two further data points can be added to this puzzle, one from the Danish "solar age", the other broadly contemporary with the Iron Age materials from Gotland. The Bronze Age votive offering from Fårdal in Jutland - the most impressive of several Bronze Age scenes Kaul sees as representing humans, snakes and 


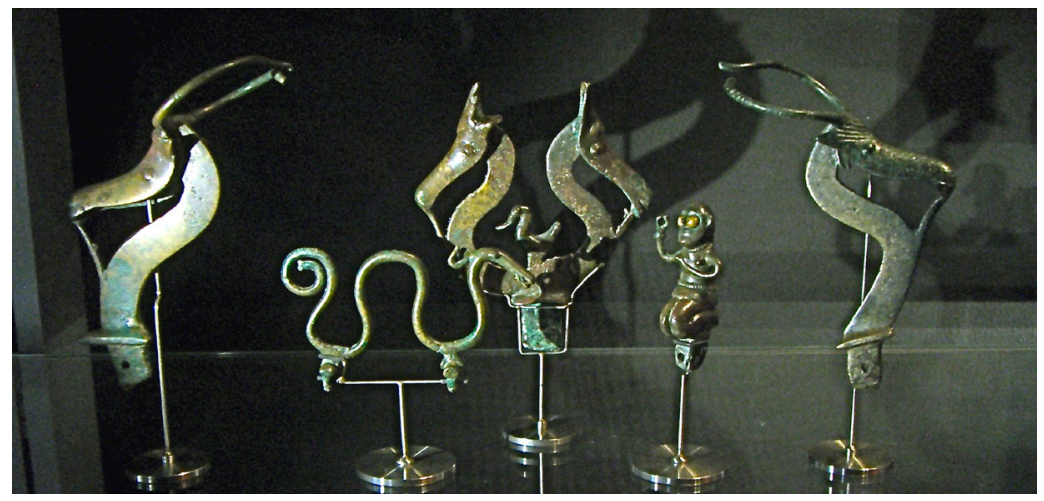

Figure 6. Bronze Age votive figures from Fårdal, Denmark. Photographer: Stephen Mitchell. Copyright: Stephen Mitchell, License: CC-BY-NC-ND.

drinking/suckling - consists of some five bronze pieces (Fig. 6), among them, a kneeling woman and a serpentine beast:

In his interpretation, Kaul argues that the woman is turning toward the snake, "and with her hand she is holding her breast, presenting her breast to the snake, as if inviting it to drink"; ${ }^{42}$ moreover, he suggests that the hole made by the woman's closed hand and the hole in the head of the serpent indicate that the two had been connected with a line.

Furthermore, recent research by Sigmund Oehrl on Gotlandic picture stones using RTI technology, and presented at the 2015 Stockholm Mythology Conference, considerably strengthens the possible correctness of the argument here. The advanced techniques offered by RTI have led Oerhl to an entirely different understanding of the depiction usually described as being of Gunnar in the snake pit on the Klinte Hunninge I picture stone (NB: see Figures $\mathrm{I} 3-\mathrm{I} 5$ in his essay in this volume). This monument was assigned by Lindqvist to the $8^{\text {th }}$ century; current research places its group to the late $8^{\text {th }}$ to $\mathrm{Io}^{\text {th }}$ centuries. ${ }^{43}$ The newly revealed tableau, especially in light of the current discussion, looks like nothing quite so much as a birthing scene - a recumbent woman, ${ }^{44}$ assisted by one, perhaps two, midwives, and accompanied by drakormar. To this, one might add Kaul's understanding that snakes in his reconstructed Bronze Age religion assisted the sun's 
transition between worlds - perhaps this function has translated over time into drakormar helping the child's transition into the world during childbirth.

Is it possible then that we see in these Iron Age materials the echoes of a tradition with deep roots involving women, drakormar, and parturition, a tradition which, at least by the time of our medieval text, has become the "myth" of Huitastierna's vision of ormar and the origin of the island's population - and also a tradition the Church appropriated to its own ends at Väte and Linde, returning closely, visually at least, to Kaul's lactating Fårdal figurine? That is a long leap, I realize, and, if anything, we should view such a scheme with healthy skepticism, but such an evolution would both explain our data and conform to them. Certainly, I do not insist on such an interpretation, yet I hope by focusing on the Gotlandic materials we now have a better purchase on how drakormar may have played a role in the lived lives of Gotlanders in the Merovingian Period and later.

\section{Notes}

I. The subject of medieval Nordic dragons has attracted considerable attention in recent years (e.g., Johansen I997; Lionarons I998; Evans 2005; Ármann Jakobsson 2010; Cutrer 2012; Acker 20I3; and Mitchell forthcoming).

2. Johansen I997. In sympathetic appreciation of the conundrum addressed by this term, I adopt its use here.

3. Skáldskaparmál, Faulkes 1998:90.

4. The terms translated as 'adder' and 'viper' - nadr and nadra would seem to be most simply understood as the gendered male and female counterparts of the same animal, as both Cleasby-Vigfusson I982 and Zoëga 1975 treat the terms, yet as an indication of the complexity associated with this category of beast, although Fritzner I973 accepts nadra as a poisonous snake (vipera), he suggests that $n a d r$ might indicate some sort of lizard-like creature (firben, øgle). Ordbog over det norrøne prosasprog notes some I 8 instances of nadra but for nadr, only the current citation in Snorra edda and as 
a sword name in Egils saga Skalla-Grimssonar. On drakorm names and swords, cf. Skáldskaparmál, Faulkes I998, st. 45 I, 459.

5. Skáldskaparmál, Faulkes I998:137.

6. Thompson 1966.

7. Watkins I995.

8. Kaul 2004a:408-409. Cp. Nordberg 20I3:232, "Kauls solara tolkningar har fått stort genomslag i de senaste decenniernas arkeologiska forskning om bronsålderns religion. Idéhistoriskt sett utgör hans studier en av de senaste länkarna i den solmytologiska skola som har sitt egentliga ursprung i romantikens idévärld, I 800-talets theologia naturalis, den evolutionistiska religionsforskningen och Max Müllers komparativa mytologi.”

9. See Kaul 2004a:369-406.

Io. Cp. Kaul's observation (I998:263), “On the other hand, the possibility cannot be excluded that the snake can have played a role in the morning." I note too that Kaul typically uses the term "snake" (slange) in his writings.

II. Kaul I998:II-I6, 22 I-4I.

I2. Johansen I997:63-I07.

I3. Johansen I997:253-54.

I4. Cf. Karnell 20I2:IO-2I.

I 5. Cf. Karnell 20I 2:I4-I 5.

I6. Cf. e.g. Andrén 2014:I36-38 et passim.

I7. Regarding this stone, see the detailed information in Guta saga, Peel 20I 5:283-284.

I 8. Recently, Pearl (20I4:I37) concludes that it belongs to "an artistic tradition that should be dated conservatively from the beginning of the $5^{\text {th }}$ century AD to the middle of the $7^{\text {th }}$ century AD."

I9. Arrhenius \& Holmquist 1960.

20. See Hermodsson 2000. 
2I. Hauk I983:556.

22. "Vår något nedslående slutsats blir alltså att vi inte har en aning om vad bildstenen berättar" (Harrison Lindberg \& Harrison 2013:64).

23.http://www.europeana.eu/portal/record/9I622/raa_kmb_I600I000 I $97924 . h t m l$. Accessed 9 January 20I6. Accessed 9 January 2016.

24. On the motif of the femme-aux-serpents, especially in medieval church art, see Luyster 200I. I take this opportunity to thank Sara Burdorff for pointing this important connection out to me.

25. From Tubach I969: \#428 I An empress, envious of another who has greater prestige than she, makes her put two snakes at her breasts. \#4888 A woman bears two sons in adultery; her first son, a hermit, has a vision of his mother in which she has two toads at her breasts and a snake about her head.

26. Ohlson 1995, who provides a survey of parallels from, e.g. three Scanian baptismal fonts (63-64). Cf. Herjulfsdotter \& Andersson 20I 2 , who suggest additional sites, as well Mackeprang (I94I:IO et passim) on the remarkable baptismal font from Vester Egede, Denmark.

27. Ohlson I995:63, “en stående kvinna med en orm vid ena bröstet." Cp. Lagerlöf I98 I:8 I, and, especially, the image and detailed description in Stenstöm I975:109-IO.

28. Guta saga, Peel I999:I9-20; Guta saga, Peel 201 5:283-84.

29. As reported in e.g. Nerman I9I7-I 924 and Nerman et al. I969-I975.

30. Cf. Nerman et al. I969-I975, II, Table I74, Nr. I45 I and III:3 I, "St. u. Lilla Ihre, Ksp. Hellvi. St. 20550 : Grab I 59."

3I. Guta saga, Peel I999:I9-20.

32. Nerman I969-I975.

33. "A small disc with a pierced decoration, about two and a half inches in diameter, was found in a woman's grave at Ihre in Hellvi parish, northeastern Gotland, and seems to depict three intertwined serpents. The grave is dated, on the basis of other finds within it, to the beginning of the ninth century" (Guta saga, Peel 201 5:283). 
34. Quoted in Guta saga, Peel 201 5:283-284.

35. Peel I999:2-3.

36. 'Womb' (in square brackets) modifies Peel's translation slightly in order to indicate that Old Gutnish barmbr (dative barmi) is used in both instances in the original as the site within which the "snakes" apparently gestate and out of which they 'crawl' (skripa).

37. Cf. Mitchell I984; Guta saga, Peel I999; 201 5; and Pearl 2015.

38. Cf. Mitchell 2014; Guta saga, Peel 2015.

39. There are, of course, other tales involving kindred beasts, such as the Tóruigheacht Dhiarmada agus Ghráinne 'Pursuit of Diarmaid and Gráinne' of the Irish Fenian cycle. On it, Persian and Nordic parallels, see Nagy 2017.

40. E.g. Herskovits \& Herskovits I938 II:248.

4I. Strelow I633: 6 .

42. Kaul 2004b:36; cf. 2004a:328-330.

43. Karnell 20I 2:I4-I 5 .

44. The character of birthing in the Germanic Iron Age is unknown: images from the Classical world often show the parturient seated, but some authorities (e.g. Soranus, Gynecology) also mention lying down. Likewise, in the Eddic poem Oddrúnargrátr, several positions are noted, with the maid saying initially (st. 4), Hér liggr Borgný, of borin verkiom ("Here lies Borgny, overcome with labour pains"). For other Old Norse examples, see Gotfredsen I982.

\section{References}

\section{Primary Sources}

Edda. Jónas Kristjánsson and Vésteinn Ólason (eds.).20 I 4. Eddukvøedi I-II. Íslenzk fornrit. Reykjavík: Hið íslenzka fornrítafélag.

_Larrington, Carolyne. 20I4. The Poetic Edda. Transl. Carolyne Larrington. Second rev. ed. Oxford: Oxford University Press.

Grímnismál, see Edda. Eddukvædi I: 367-79. 
Guta saga. Peel, Christine. 20 I 5. Guta Lag and Guta Saga. The Law and History of the Gotlanders. Medieval Nordic Laws. Ed. and transl. Christine Peel. New York: Routledge. (Guta Saga originally published as Guta saga. The History of the Gotlanders. Ed. and tr. Christine Peel. I999. Viking Society for Northern Research. Text Series, I 2. London: Viking Society for Northern Research).

- Strelow, Hans Nielsen. 1633. Cronica Guthilandorum. Copenhagen: Prentet aff M. Martzan.

Gylfaginning. Faulkes, Anthony. 2005. Snorri Sturluson. Edda. Prologue and Gylfaginning. Ed. Anthony Faulkes. Second ed. London: Viking Society for Northern Research. University College London, 2005 .

Faulkes, Anthony. 1995. Snorri Sturluson. Edda. Transl. Anthony Faulkes. London: J.M. Dent.

Oddrúnargrátr, see Edda. Eddukvædi II: 365-7I.

Skáldskaparmál. Faulkes, Anthony. 1998. Snorri Sturluson. Edda. Skáldskaparmál. I. Introduction, Text and Notes. Ed. Anthony Faulkes. London: Viking Society for Northern Research. University College London.

Faulkes, Anthony. 1995. Snorri Sturluson. Edda. Transl. Anthony Faulkes. London: J.M. Dent.

Voluspá, see Edda. Eddukvædi I: 292-39I.

\section{Secondary Literature}

Acker, Paul. 2013. Dragons in the Eddas and in Early Nordic Art. In P. Acker \& C. Larrington (eds.). Revisiting the Poetic Edda. Essays on Old Norse Heroic Legend. New York: Routledge, 53-75.

Andrén, Anders. 20I4. Tracing Old Norse Cosmology. The World Tree, Middle Earth, and the Sun from Archaeological Perspectives. Vägar till Midgård, I6. Lund: Nordic Academic Press.

Ármann Jakobsson. 20I0. Enter the Dragon. Legendary Saga Courage and the Birth of the Hero. In M. Arnold \& A. Finlay (eds.). Making History. Essays in Fornaldarsögur. London: Viking Society for Northern Research, 33-52. 
Cleasby, Richard and Gudbrand Vigfusson (eds.). I982 (1957). An Icelandic-English Dictionary. Second rev. ed. by William Craigie. Oxford: The Clarendon Press.

Cutrer, Robert. 2012. The Wilderness of Dragons. The Reception of Dragons in Thirteenth century Iceland. M.A. thesis, Háskóli Íslands.

Evans, Jonathan. 2005. 'As Rare as They are Dire'. Old Norse Dragons, Beowulf, and the Deutsche Mythologie. In T. A. Shippey (ed.). The Shadow-Walkers. Jacob Grimm's Mythology of the Monstrous. Arizona Studies in the Middle Ages and the Renaissance, I4. Tempe, Arizona: Arizona CMRS (with Brepols), 207-269.

Fritzner, Johan (ed.). I973 (I 886). Ordbok over Det gamle norske Sprog. 4th rev. ed. Oslo, etc.: Universitetsforlaget.

Gotfredsen, Edvard. I982 (I956-I978). Barsel. In J. Brøndsted et al. (eds.). Kulturhistorisk leksikon for nordisk middelalder. Copenhagen: Rosenkilde og Bagger: I, cols. 354-365.

Gräslund, Anne-Sofie. 2006. Wolves, Serpents and Birds. Their Symbolic Meaning in Old Norse Belief. In A. Andrén et al. (eds.). Old Norse Religion in Long-Term Perspective. Origins, Changes, and Interactions. Vägar till Midgård. Lund: Nordic Academic Press, I 24-I 29.

Harrison Lindbergh, Katarina, \& Harrison, Dick. 20I3. IO I föremål ur Sveriges historia. Stockholm: Norstedts.

Hauk, Karl. 1983. Text und Bild in einer oralen Kultur. Antworten auf die zeugniskritische Frage nach der Erreichbarkeit mündlicher Überlieferung im frühen Mittelalter. Zur Ikonologie der Goldbrakteaten XXV. In Frühmittelalterliche Studien I7, 5 I O-599.

Herjulfsdotter, Ritwa, \& Andersson, Tommy. 20I2. Luxuria eller Terra på relieferna i Siene och Strö? In Skara stiftshistoriska sällskap. Medlemsblad 20:I, 8-IO.

Hermodsson, Lars. 2000. En invandrad gud? Kring en märklig gotländsk bildsten. In Fornvännen 95, I09-I I 8.

Herskovits, Melville J. \& Herskovits, Frances S. I938. Dahomey. An Ancient West African Kingdom. New York: J.J. Augustin. 
Johansen, Birgitta. 1997. Ormalur. Aspekter av tillvaro och landskap. Stockholm Studies in Archeology, I4. Stockholm: Arkeologiska institutionen. Stockholms universitet.

Karnell, Maria Herlin (ed.). 20I2. Gotlands bildstenar. järnålderns gåtfulla budbärare. Gotländskt arkiv, 84. Visby: Fornsalens Förlag.

Kaul, Flemming. 1998. Ships on Bronzes. A Study in Bronze Age Religion and Iconography. Studies in Archaeology \& History, 3. Copenhagen: National Museum of Denmark.

Kaul, Flemming. 2004a. Bronzealderens religion. Studier af den nordiske bronzealders ikonografi. Copenhagen: Det Kongelige Nordiske Oldskriftselskab.

Kaul, Flemming. 2004b. Bronzealderens religion. Studier af den nordiske bronzealders ikonografi. Dansk resumé. English Summary. Copenhagen: Det Kongelige Nordiske Oldskriftselskab.

Lagerlöf, Erland. I98 I. Linde kyrka (Fardhems ting, Gotland, VII:2). Sveriges kyrkor, konsthistoriskt inventarium, I86. Stockholm: Almqvist \& Wiksell.

Lionarons, Joyce Tally. 1998. The Medieval Dragon. The Nature of the Beast in Germanic Literature. Enfield Lock, Middlesex: Hisarlik Press.

Luyster, Amanda. 200I. The Femme-aux-serpents at Moissac. Luxuria (lust) or a Bad Mother? In S.R. Asirvatham et al. (eds.). Between Magic and Religion. Interdisciplinary Studies in Ancient Mediterranean Religion and Society. Lanham: Rowman \& Littlefield, I65-I9I.

Mackeprang, Mouritz. I94I. Danmarks middelalderlige Døbefonte. Copenhagen: Selskabet til Udgivelse af Skrifter om Danske Mindesmærker.

Mitchell, Stephen A. I984. On the Composition and Function of Gutasaga. In Arkiv för nordisk filologi 99, I 5 I-I74.

Mitchell, Stephen. 20I4. The Mythologized Past. Memory and Politics in Medieval Gotland. In P. Hermann et al. (eds.). Minni and Muninn. Memory in Medieval Nordic Culture. Acta Scandinavica, 4. Turnhout: Brepols, I 55-I74. 
Mitchell, Stephen. forthcoming. Dragons, a Cryptozoological Journey into the Nordic Otherworld. In J.F. Nagy (ed.). Comparing Dragons. Ancient, Medieval, and Modern. UCLA CMRS. Mundi. Turnhout: Brepols.

Nagy, Joseph Falaky. 20I7. Vermin Gone Bad in Medieval Scandinavian, Persian, and Irish Traditions. In P. Hermann et al. (eds.). Old Norse Mythology in Comparative Perspectives. Cambridge: Harvard University Press.

Nerman, Birger. I9I7-I924. Gravfynden på Gotland under tiden $55^{\circ}-$ 800 e. K. In Antikvarisk Tidskrift för Sverige 22:4, I-IO2, I-XXX.

Nerman, Birger et al. 1969-1975. Die Vendelzeit Gotlands. Monographien hg. von der Kungl. Vitterhets, historie och antikvitets akademien, 48, 55. Stockholm: Almqvist \& Wiksell.

Nordberg, Andreas. 20I3. Fornnordisk religionsforskning mellan teori och empiri. Kulten av anfäder, solen och vegetationsandar $i$ idehistorisk belysning. Acta Academiae Regiae Gustavi Adolphi, I 26. Uppsala: Kungl. Gustav Adolfs Akademien för svensk folkkultur.

Oehrl, Sigmund. 20 I 2. Ikonografiska tolkningar av gotländska bildstenar baserade på nya analyser av ytorna. In M. H. Karnell (ed.). Gotlands bildstenar. Järnålderns gåtfulla budbärare. Gotländskt arkiv, 84. Visby: Fornsalens Förlag, 9I-ı०6.

Oehrl, Sigmund. 20 I7. Re-Interpretations of Gotlandic Picture Stones Based on the Reflectance Transformation Imaging Method (RTI). Some Examples. In K. af Edholm et al. (eds.). Myth, Materiality, and Lived Religion in Merovingian and Viking Scandinavia. Stockholm: Stockholm University Press.

Ohlson, Elisabeth. I995. Själajakt och fruktbarhetssymbolik. Romanska reliefer på de gotiska kyrkorna i Grötlingbo och Väte. In Gotländskt arkiv 66, 49-66.

Pearl, Frederic B. 20I4. The Water Dragon and the Snake Witch. Two Vendel Period Picture Stones from Gotland, Sweden. In Current Swedish Archaeology 22, I37-I 56.

Peel, Christine. I999. Guta saga. The History of the Gotlanders. Ed. and transl. Christine Peel. Viking Society for Northern Research. Text Series, I 2. London: Viking Society for Northern Research. 
Peel, Christine. 20 I 5. Guta Lag and Guta Saga. The Law and History of the Gotlanders. Ed. and transl. Christine Peel. Medieval Nordic Laws. New York: Routledge.

Stenstöm, Tore. I975. Problem rörande Gotlands medeltida dopfuntar. PhD Diss. Umeå: Umeå Universitet.

Thompson, Stith (ed.). I966. Motif-Index of Folk-Literature. Second rev. ed. Bloomington: Indiana University Press.

Tubach, Frederic C. 1969. Index Exemplorum. A Handbook of Medieval Religious Tales. Folklore Fellows Communications, 204. Helsinki: Akademia Scientiarum Fennica.

Watkins, Calvert. 1995. How to Kill a Dragon. Aspects of IndoEuropean Poetics. New York: Oxford University Press. 


\section{Response}

Judy Quinn

University of Cambridge

\section{Of Snakes and Women - The Interpretation of the Early Stone Carvings of Gotland}

In their illustrated survey of Romanesque sexual carvings, Weir and Jarman ${ }^{\mathrm{I}}$ document an extraordinary array of what they term "images of lust", which are linked to detailed maps of church locations across western Europe (should the reader be curious enough to wish to visit the carvings in situ). The carvings, designed to serve as admonishment against the sin of fornication, focus on the organs of lust belonging to both male and female bodies. While one carving shows a figure whose testicles are being bitten by a snake, ${ }^{2}$ the majority of the depictions are of female bodies, in keeping with Christian theology's fixation on the female body as a locus of sin. To highlight the afflictions that the damned might expect, other animals including toads, fish and unicorns are shown gnawing sensitive bodily areas. Those that target a woman's breasts often present a particularly disconcerting picture, the attachment of mouth to breast closely resembling the maternal suckling of infants. It is possible that viewers of the medieval iconography may have been influenced to some extent in their interpretation of the image by the antique iconography of the so-called earthmother (Terra), who was depicted suckling animals as well as children. A favourite motif among Romanesque carvers, a snake biting a woman on her breast (dubbed la femme aux serpents), is attested across a wide geographical area, from northern Spain to Italy, to Britain and Ireland in the west and Germany and Scandinavia in the north. Emile Mâle charted the migration of the iconography across Europe, identifying what he thought were probably its earliest forms in the Languedoc region. ${ }^{3}$ Three examples from Denmark (Bråby, Gosmer and Vester Egede) are listed by Weir and Jarman, ${ }^{4}$ who also note that the example from Väte Church in Gotland closely resembles a carving from 
Saint-Jouin-de-Marnes in northern France. ${ }^{5}$ La femme aux serpents also shares some characteristics with another well-attested figure from the same period, the sheela-na-gig, or 'female exhibitionist', depicted with legs akimbo and often flanked by beasts. ${ }^{6}$ Such a posture and composition is, however, also attested in much earlier cultures, including in Etruscan artefacts.

The symbolism of the snake is as complex as its attestation is widespread across world cultures, the reptile sometimes playing a beneficent role in relation to human society, sometimes representing a threat and sometimes twisting and turning between the two. That the island of Gotland preserves some striking carvings that depict a female figure with a snake is intriguing, as Stephen Mitchell has shown in his paper, even if the relationship between the traditions behind them may not go far beyond geographical proximity. The carving on Väte Church, with its clear connection to the Romanesque tradition of la femme aux serpents, dates from the twelfth century. The carving on the När Smiss III stone, a stylised depiction of a figure with an ornate headdress or hairstyle, holding a stylised reptile in each hand, facing forward and with widely splayed legs, is dated to at least five centuries earlier (and possibly as many as seven centuries earlier). The implied relationship of woman to reptile is markedly different in each image: in the earlier carving, the sexualised figure is assertive and in command of the reptiles; in the later one, she appears to tug the bodies of the reptiles away from her breasts unsuccessfully with her outwardly-bowed arms. As Mitchell notes, the theological motivation of the carver of the Väte image may have included reference to a punishment specifically designed for negligent mothers, who were condemned to breastfeed inappropriate species. ${ }^{7}$

In situating his interpretation of the När Smiss III and Väte carvings within the "adversarial 'man versus monster' scenario" of Indo-European tradition, and using as his point of reference the popular Christian presentation of dragons in the Nordic Middle Ages to argue that the "principal way these beasts ought to be understood is within an adversarial context", Mitchell downplays the gender specificity of the Gotlandic works. As he notes, another trajectory is taken by scholars such as Flemming Kaul and Birgitta Johansen, whose interpretations accommodate a productive 
symbiosis in the relationship between humans and snakes in the pre-Christian era, particularly with regard to women. Textual evidence also supports the notion that a snake was a positive symbol in the context of Gotlandic traditions, with an episode in the so called Legendary History of Gotland presenting coiled snakelings within a woman's body as a figuration of dynastic prosperity: the snakes emerge as three sons, playing an entirely positive role in a foundation legend for the island. ${ }^{8}$ There is considerable evidence, therefore, that, in the semantics of early Gotlandic culture, a woman in the company of snakes was without any negative connotation unless - or possibly until - the image is fully saturated by Christian demonization of the reptile (and to some extent, of women).

In plotting "data points" to facilitate the interpretation of images, some caution needs to be exercised in deducing features that can be considered analogous. The doubt cast by Sigmund Oehrl in his essay in this volume on the standard interpretation of one of the tableaux on the Klinte Hunninge I picture stone and his postulation of other possible scenarios it might reference is a case in point. By fading out Sune Lindqvist's enhancement of the carving, Oehrl has shown that the tableau is unlikely to represent Gunnarr in the snake-pit (the recumbent figure appears to be female) and tentatively proposes two alternative interpretations: a representation of 'the Christian idea of a post-mortem place of punishment', or a depiction of the myth of Loki's punishment, with Skaði affixing a snake above (a feminised) Loki while Sigyn returns to the enclosure with the emptied venom-catching bowl. Citing Oehrl's work as 'strengthen[ing] considerably the possible correctness of the argument here', Mitchell speculates that the scene may represent something else entirely: "a birthing scene - a recumbent woman, assisted by one, perhaps two midwives, and accompanied by drakormar". In the interpretation of Gotlandic tradition, a female figure in the company of snakes can certainly fire the imagination!

While it is fair to consider the images on När Smiss II, Klinte Hunninge I and on Väte Church within a matrix - they are all carved on stone and located in Gotland, and they depict female figures and snakes - their cultural semantics seem to me so 
dissimilar that it is hard to construe one through the other, especially an earlier image through a later one. That is not to say that later medieval parishioners' interpretation of När Smiss III might not have been coloured by the Väte image. A reading of När Smiss III through the data points of Mitchell's matrix, however, does not seem to me to get us any closer to the lived religion or thought-world of pre-Christian Gotland. The Harrisons' conclusion regarding När Smith II that Mitchell quotes is not so much "pessimistic" as an acknowledgement of the wonderful otherness of the past, where images of snakes, and indeed women, may have encoded meanings that centuries of Christian-inflected pondering have not yielded up.

\section{Notes}

I. Weir \& Jarman 1999.

2. Weir \& Jarman I999:75, Fig. 27a.

3. Mâle I978:375ff.

4. Weir \& Jarman I999:68-69, Fig. 22.

5. Weir \& Jarman I999:62, Plate 28; 68.

6. Weir \& Jarman I999:I I-20; $70 f f$.

7. This interpretation is based on Luyster 200I.

8. Peel I999:2-3.

\section{References}

Peel, Christine, ed. and transl. 1999. Guta saga. The History of the Gotlanders. Viking Society for Northern Research. Text Series, I 2. London: Viking Society for Northern Research.

Harrison Lindbergh, Katarina \& Harrison, Dick. 20I3. IO I föremål ur Sveriges historia. Stockholm: Norstedts, 6I-64.

Johansen, Birgitta. 1997. Ormalur. Aspekter av tillvaro och landskap. Stockholm Studies in Archeology, I4. Stockholm: Arkeologiska institutionen, Stockholms universitet. 
Kaul, Flemming. 2004. Bronzealderens religion. Studier af den nordiske bronzealders ikonografi. København: Det Kongelige Nordiske Oldskriftselskab.

Lindqvist, Sune. I94I-I942. Gotlands Bildsteine I-II. Stockholm: Wahlström \& Widstrand.

Luyster, Amanda. 200I. "The Femme-aux-serpents at Moissac: Luxuria (lust) or a Bad Mother?" In: S.R. Asirvatham, C.O. Pache and J. Watrous (eds.), Between Magic and Religion: Interdisciplinary Studies in Ancient Mediterranean Religion and Society. Lanham: Rowman \& Littlefield, I65-I9I.

Mâle, Emile. 1978. Religious Art in France, the Twelfth Century. A Study of the Origins of Medieval Iconography. Princeton: Princeton University Press.

Weir, Anthony \& Jerman, James. I999 (I986). Images of Lust. Sexual Carvings on Medieval Churches. First published by Batsford 1986. London: Routledge. 
